\title{
Profiting from the paradigm shift in scholarly journal publishing: The case of predatory publishers
}

\author{
Lyombe Eko PhD, Amy Koerber PhD
}

In December 2019, the well-known scientific journal Nature published an article entitled, "Predatory journals: no definition, no defence."1 The collaborative effort, which was co-authored by a record 35 authors from scientific, technical, and medical publishers around the world, was illustrated by an eye-catching piece of art based on the primeval myth of deceptive appearances-a sinister-looking wolf in sheep's clothing. In the illustration, the "clothing" that the wolf uses as its camouflage is an open academic journal with a sheep on its cover. That article raised the alarm about a phenomenon that the researchers, who represented fields of research, education, libraries, publishing, and research funding, consider a "global threat."1

Scholarly publication is, like science, a paradigm, or way of seeing, organizing, and representing reality. Scholarly publishing across the disciplines is comprised of specialized, self-regulating "fields" of knowledge production, processing, curation, archiving, and retrieval. ${ }^{2}$ Scholarly publication is part of the knowledge production-and-creation paradigm of research and publication. Predatory journals are considered the tares of this paradigm. Predatory publishers and journals first caught the attention of the scientific community in 2008 when Jeffrey Beall, a librarian at the University of Colorado-Denver, coined the term to characterize a small number of open access journals and publishers that he included on a blacklist he had published on his website. Predatory journals are considered a bane to the field because they do not care for tried and true publication standards. They ride roughshod over publication ethics in order to monetize academic publication and make a quick buck. The term, "predatory journal" or "predatory publisher" has become a contemptuous, denunciative, and exclusionary epithet that members

Corresponding author: Amy Koerber

Contact Information: Amy.Koerber@ttu.edu

DOI: 10.12746/swrccc.v8i35.715 of the commercial and academic scholarly publishing industry have accepted as the appropriate nomenclature for the new category of unorthodox, commercial publishers that began to enter the scholarly publishing market in the early 2000 s.

Grudniewicz et al. advanced the following "consensus" definition of predatory journals and publishers:

Predatory journals and publishers are entities that prioritize self-interest at the expense of scholarship and are characterized by false or misleading information, deviation from best editorial and publication practices, a lack of transparency, and/ or the use of aggressive and indiscriminate solicitation practices. $^{1}$

Johnson et al. described the modus operandi of predatory journals, whose business model is to prey on unsuspecting researchers and professors who, driven by the "publish or perish" globalized ethos of American higher education, are always on the lookout for publication outlets for their research. These journals "often promote themselves to potential authors through bulk, sometimes SPAM emails, frequently have fictitious editorial boards and in many cases use the Gold Open Access [article publication charge] model to get money upfront before an author can detect whether their article has been subjected to any peer review whatsoever."3 It is estimated that there are more than 9,000 verified predatory journals generating some $\$ 75$ million in revenues annually. Furthermore, some predatory publishers have been known to deliberately confuse article submitters. They do this by hijacking some legitimate journals and creating fraudulent websites that mimic the legitimate journal in order to attract submissions and fraudulently collect article publication charges. ${ }^{3}$

When Grudniewicz et al. declared that, "Predatory journals are a global threat,"1 they were not particularly referring to the financial impact of these publishers because from a journal economics and market-size perspective, the revenues of predatory journals are 
miniscule compared to the close to $\$ 26$ billion dollar revenues of the scientific, technical and medical publishing industry. ${ }^{3}$ Rather, the danger that predatory publishers pose to the scholarly or academic publishing industry is existential because they undermine the fundamental philosophy and ethics of the academic peer review process. Johnson et al. present an interesting summary of the quality control purpose of peer review that is being undermined by predatory journals. They state that the fundamental purpose of peer review is "to ensure that only good science or scholarship gets published, and that work that does not meet acceptable standards does not enter the journal literature." 3 Scholarly publication has certain frameworks or "contextual matrixes," to borrow the expression of Pierre Legrand ${ }^{4}$ that shape and structure its modus operandi. By skipping the scientific publication paradigm, predatory journals have introduced discordant realities into the scholarly publication process.

\section{FERMENT IN THE FIELD OF SCHOLARLY PUBLICATION AND THE EMERGENCE OF PREDATORY PUBLISHERS}

Predatory publishing is a money-making phenomenon that emerged in the first decade of the $21^{\text {st }}$ century, and took advantage of the internal contradictions, shortcomings, and ferment in the field of scholarly journal publication. Predatory publishers emerged in the field of scholarly publication at a time of "radical discontinuities," to borrow the expression of Corfield ${ }^{5}$ that had led to a ferment in the field of scholarly publication. These discontinuities included: 1) systemic flaws and contradictions, hyper competitiveness and disequilibrium of the academic research paradigm and scholarly publishing industry, 2) the electronic revolution and the resultant digitization and transfer of journal archives and publications from the physical spaces of libraries and archives to the Internet and cyberspace, and 3 ) the emergence of Open Access Publishing with its lucrative article publication charge business model.

At the end of World War II, the United States was the undisputed center of higher education and scientific research. The scholarly publishing industry took advantage of the post-war economic boom and used different business and marketing strategies to create demand for scholarly publications in science, technology, and medicine as well as in the humanities and the social sciences. ${ }^{6}$ Alberts et al. suggest that generous research funding by the National Institutes of Health (NIH), National Science Foundation, and numerous other federal agencies, foundations, and academic institutions led to a "remarkable outpouring of innovative research from American laboratories."7 However, these professionals suggest that the system that has flourished in the last 60 years is no longer sustainable and that there is widespread malaise whose root cause is, "the longstanding assumption that the biomedical research system in the United States will expand indefinitely at a substantial rate." They believe that the expansion of research and research funding stalled in the last decade as a result of reduction in federal funding. The result is what they call "hypercompetition for the resources and positions that are required to conduct science."7

Some researchers and scientists consciously participate in the activities of predatory journals—-thereby giving them a modicum of respectability-under the belief (often mistaken) that by reviewing for, and publishing in predatory journals, they would be in a position to point out the shortcomings of these journals and thereby improve their standards. ${ }^{1,8}$ These researchers see predatory journals, despite their poor reputation, as an alternative to well-funded, elite "Big Science," "Big Research," and legacy science, technology, and medicine publishing, that is getting bigger and bigger, more and more exclusive, and harder for regular researchers and faculty members to feature in.

\section{THE INFORMATION AND COMMUNICATION TECHNOLOGY REVOLUTION AND TRANSFER OF KNOWLEDGE CURATION AND RETRIEVAL FROM REAL SPACE TO CYBERSPACE}

Predatory scholarly publishing emerged during the transition of scholarly publishing from physical to online digital spaces. The availability of databases, computers, the Internet and commercial interactive server applications facilitated the digitization and transfer of knowledge from physical information storage spaces (libraries and archives) to the dematerialized world of cyberspace for easy access and retrieval. Federal policy orientations promoted a market-based approach 
to the Internet and information and communication technologies. In 1997, the Clinton-Gore administration offered the world a vision and framework for the expansion and regulation of global electronic commerce on the fledgling Internet. This was a laissez-faire, capitalist, free-market, free-flow-of-information framework under which governments were to assume a minimalist regulatory posture towards the Internet. ${ }^{9}$ In 2004, Google, the world's largest Internet search company, announced that it had launched The Google Books Library Project. This was an innovative project that would radically transform how human beings create, store, retrieve, and use information. The Google Books project involved "space-shifting," the digitization and transfer of whole books -including bound scholarly journals-from the real, physical geographic spaces of libraries and archives to databases and servers in cyberspace, where Internet search results would display snippets from these books and journals to readers as part of Google's commercial search or linguistic capitalist business model. ${ }^{10,11}$

As a result, newspaper, magazine and journal publishers licensed their archives of collective works (periodicals) to electronic databases like Lexis-Nexis, which digitized these articles and stored them in paywalled interactive databases where they are searchable, retrievable, downloadable, printable, and readable in a number of digital formats as single entities separated from the original collective periodical volumes in which they had been published. Digital databases essentially became another lucrative revenue stream for both commercial and university journal publishers. ${ }^{11}$

\section{PARADIGM SHIFT IN SCHOLARLY PUBLISHING: THE OPEN ACCESS MOVEMENT}

Perhaps the most important development was the advent of paradigm-shifting "open access" publishing. Johnson et al. suggest that the proportion of the scientific output published in journals under the ownership of large commercial publishers has risen steadily over the past 40 years, and even more so since the advent of the digital era. ${ }^{3}$ These corporations became bigger and bigger to the point at which the multi-billion-dollar scholarly journal publishing industry became highly skewed and highly concentrated in the hands of a few oligopolistic multi-multinational corporations and a handful of university presses. ${ }^{3}$ Under this corporate and university publishing model, publishers had a monopoly on the unique collections of articles their scholarly journals published. Brown et al. suggest that due to these monopolies, researchers and scientists who needed the information contained in journal articles were obliged to pay whatever price the journal publishers asked. ${ }^{12}$

In response to the subscriptions and site-licensing fee model of the scholarly journal industry, and the throttling effect of this model on the dissemination of knowledge and information, in 2000, a number of high profile American researchers, including Nobel prize winner, Harold Varmus, sought "to catalyze a revolution in scientific publishing" by proposing a paradigm shift ${ }^{13}$ in scholarly journal publication and economicsan "open access" publication model. ${ }^{12}$ They stated that the "essential rationale of the pay-for-access model has disappeared, now that electronic publication and Internet distribution have become routine. Instead, this business model is what stands in the way of all the benefits of open access."12 This open access model would be different from the traditional pay to access business model of scholarly publication. The open access publication model they were proposing was premised on the idea that everything published "will immediately be freely available to anyone, anywhere, to download, print, distribute, read, and use without charge or other restrictions, as long as proper attribution of authorship is maintained." 12

They were arguing not for the elimination of the traditional pay for access journal publishing paradigm; they were arguing for a paradigm shift in the subscription and licensing model of journal economics. They argued that the electronic revolution and the Internet had led to an information society in which whole sectors of the knowledge economy had been digitized and transferred to cyberspace. Therefore, the traditional scholarly publishing model of printing and distributing scientific journals was no longer cost effective or even sustainable. $^{12}$

This proposed open access publication model would be grounded on the fact that scientific research and publication go hand in hand. As such, open access publishing would be funded by research funders as part 
of research grant budgets. Brown et al. also argued for a free-market, journal economics approach, stating that "Open access would eliminate [corporate and university] monopolies over essential published results, diminishing profit margins and creating a more efficient market for scientific publishing-a market in which publishers would compete to provide the best value to authors (high quality, selectivity, prestige, a large and appreciative readership) at the best price." ${ }^{2}$ They submitted that the open access model, and especially its article processing charge component would be so successful that it would revolutionize scholarly journal publishing. Commercial scholarly journal publishers initially objected to this model but due to its early success, they ultimately hopped on the bandwagon and offered both open access journals and open access books. Unfortunately, due to reductions in federal and institutional funding, the burden of paying for scholarly publication under this model soon fell on scholars and authors desperate to publish to advance their careers. This development paved the way for the emergence of predatory journals, which mimic open access publishing and capitalize on its lucrative article publication charge model. Researchers need to be aware of the problematic nature of predatory publishers before they submit their research and hard earned cash to them.

Keywords: scientific publications, open access, predatory journals

Article citation: Eko L, Koerber A. Profiting from the paradigm shift in scholarly journal publishing: the case of predatory publishers. The Southwest Respiratory and Critical Care Chronicles 2020;8(35):61-64

From: College of Media \& Communication, Texas Tech University

Submitted: $5 / 6 / 2020$

Accepted: $7 / 7 / 2020$

Conflicts of interest: none

This work is licensed under a Creative Commons

Attribution-ShareAlike 4.0 International License.

\section{REFERENCES}

1. Grudniewicz A, Moher D, Cobey K, et al. Predatory journals: no defence. Nature 2019, 11 Dec Retrieved from: https://www.nature.com/articles/d41586-019-03759-y

2. Bourdieu P. Outline of a Theory of Practice. Trans. Richard Nice; Cambridge, U.K.: Cambridge University Press, 1977.

3. Johnson R, Watkinson A, Mabe M. The STM Report: An Overview of Scientific and Scholarly: 1968-2018 (5 $5^{\text {th }}$ Ed.). The Hague: Netherlands: International Association of Scientific, Technical and Medical Publishers. https://www. stm-assoc.org/2018_10_04_STM_Report_2018.pdf

4. Legrand P. The Same and the Different. In Legrand P, Munday R, editors. Comparative Legal Studies: Traditions and Transitions. Cambridge: Cambridge University Press; 2003. p. 240-311.

5. Corfield P J. Time and the Shape of History. New Haven: Yale University Press; 2007

6. Greco, A. N. The Growth of the Scholarly Publishing Industry in the United States: A Business History of a Changing Marketplace, 1939-1946, New York: Palgrave Macmillan, 2019.

7. Alberts B, Kirschner M, Tilghman, et al. Rescuing us biomedical research from its systemic flaws. Proceedings of the National Academy of Sciences U.S.A. (PNAS) 2014 Apr 22; 111(16):5773-5777.

8. Van Noorden R. Hundreds of scientists have peer-reviewed for predatory journals. Nature 2020, 10 Mar. Retrieved from: DOI: 10.1038/d41586-020-00709x. Retrieved from: https:// www.nature.com/articles/d41586-020-00709-x

9. Clinton W, Gore A. A Framework for Electronic Commerce. Washington D.C.: United States Printing Office; 1997.

10. Kaplan F. Linguistic Capitalism and Algorithmic Mediation. Representations 2014;127(1):57-63.

11. Eko L. American Exceptionalism, the French Exception and Digital Media Law. Lanham, MD. Lexington Books; 2013.

12. Brown P, Eisen M, Varmus H. Why PLoS Became a Publisher. PLoS Biology 2003; Oct; 1(1):e36. Published online 2003 Oct 13. doi: 10.1371 /journal.pbio. 0000036

13. Kuhn T. The Structure of Scientific Revolutions. Chicago: University of Chicago Press; 1970. 